\title{
Uil norden
}

\section{Ramprogram 2013-2016}

för det nordiska samarbetet inom fiske och vattenbruk, jordbruk, livsmedel och skogsbruk

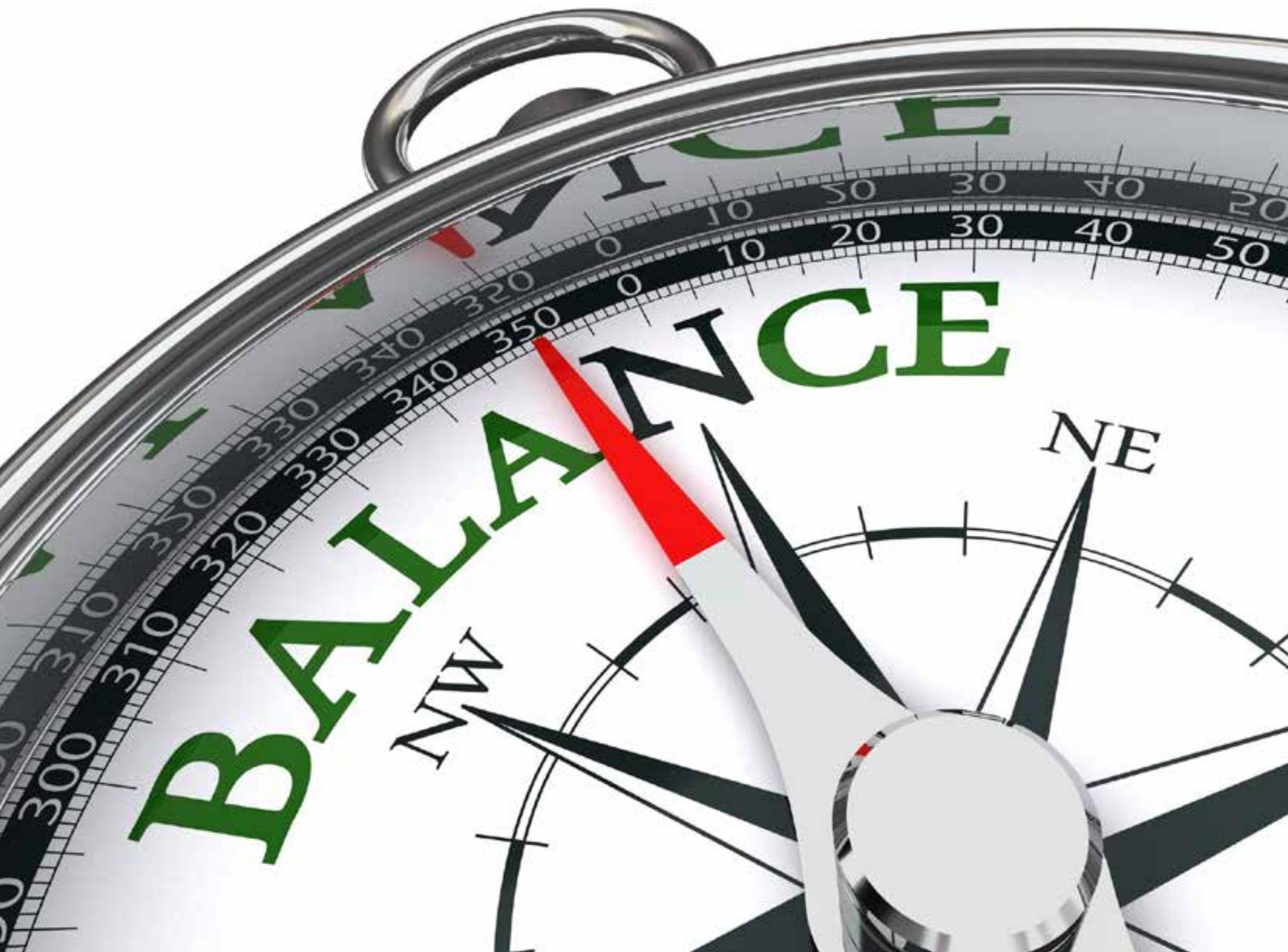


Ramprogram 2013-2016

för det nordiska samarbetet inom fiske och vattenbruk, jordbruk, livsmedel och skogsbruk

ISBN 978-92-893-2524-0

http://dx.doi.org/10.6027/ANP2013-741

ANP 2013:741

(C) Nordiska ministerrådet, 2013

Layout: Jette Koefoed/Nordiska ministerrådet

Fotos: Image Select

Omslag: Image Select

Typsnitt: Meta Book LF

Papper: Munken Polar

Tryck: Scanprint

Upplaga: 1000

www.norden.org/sv/publikationer

Printed in Denmark

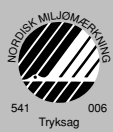

Nordiska ministerrådet

Ved Stranden 18

DK-1061 København K

Telefon (+45) 33960200

www.norden.org

\section{Det nordiska samarbetet}

Det nordiska samarbetet är ett av världens mest omfattande regionala samarbeten. Det omfattar Danmark, Finland, Island, Norge och Sverige samt Färöarna, Grönland och Åland.

Det nordiska samarbetet är politiskt, ekonomiskt och kulturellt förankrat och är en viktig partner i europeiskt och internationellt samarbete. Den nordiska gemenskapen arbetar för ett starkt Norden i ett starkt Europa.

Det nordiska samarbetet ska stärka nordiska och regionala intressen och värderingar i en global omvärld. Gemensamma värderingar länderna emellan bidrar till att stärka Nordens ställning som en av världens mest innovativa och konkurrenskraftiga regioner. 


\section{norden}

\section{Ramprogram 2013-2016}

för det nordiska samarbetet inom fiske och vattenbruk, jordbruk, livsmedel och skogsbruk 


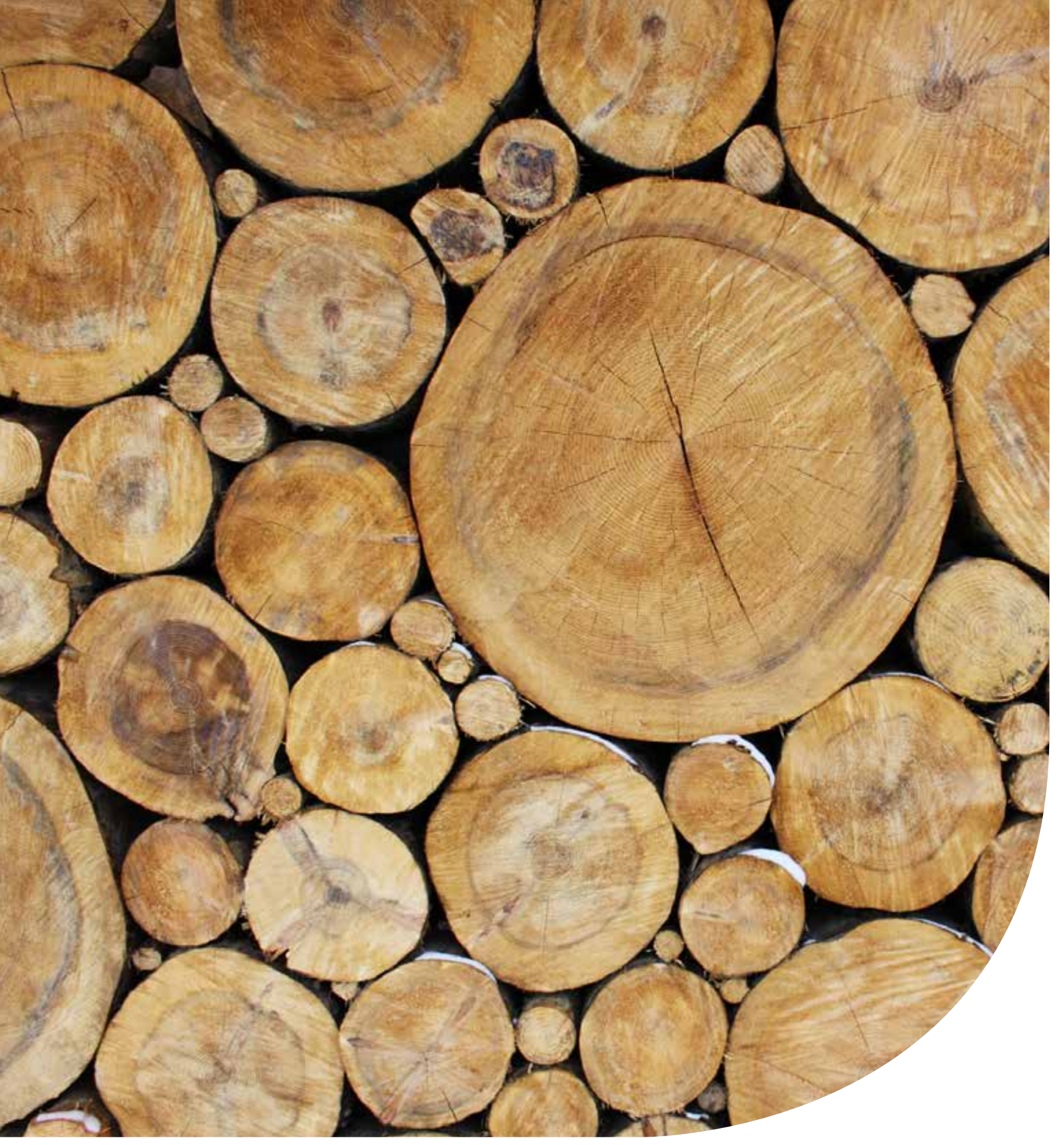




\section{VISION}

för det nordiska samarbetet inom MR-FJLS

\section{Naturresurser}

Hållbarhet

Konkurrenskraft

\section{Välfärdsutveckling}

Hållbarhet och konkurrenskraftig produktion i den gröna och blå sektorn av varor och tjänster med nordiska biologiska naturresurser som bas - till gagn för en hållbar utveckling av välfärden i Norden. 


\title{
Ramprogram 2013-2016
}

\author{
för det nordiska samarbetet inom fiske \\ och vattenbruk, jordbruk, livsmedel \\ och skogsbruk
}

Ramprogrammet anger inriktningen för det nordiska politiska samarbetet inom fiske och vattenbruk, jordbruk, livsmedel och skogsbruk under perioden 2013-2016 inom Nordiska ministerrådet. Ramprogrammet ger möjligheter och beskriver de centrala utmaningarna på området.

Ordförandeprogrammet för de enskilda åren preciserar och kompletterar ramprogrammet. Dessa utgör tillsammans handlingsprogrammet för samarbetet.

Utöver detta har i ramprogrammet beaktats de prioriteringar och strategier inom Nordiska ministerrådet som sätts upp av statsministrarna, samarbetsministrarna och övriga ministerråd när man arbetar med teman och problemställningar inom vilka MR-FJLS kan bidra.

Målet med arbetet inom MR-FJLS är att främja en hållbar utveckling inom de fyra sektorerna fiske och vattenbruk, jordbruk, livsmedel och skogsbruk.
Målet är att förbättra förutsättningarna för en ekonomisk tillväxt och välfärdsutveckling och samtidigt bidra till att säkerställa en bättre miljömässig, hälsomässig och social/regional utveckling.

Utgångspunkten för samarbetet är att det ger mervärde för länderna och skapar nordisk nytta. De nordiska länderna samarbetar för att hitta lösningar och identifiera möjligheter för utvecklingen inom MR-FJLS-området, där ministrarna dels har ett ansvar när det gäller företag som utnyttjar naturresurser, dels har ansvar för konsumentskydd.

Den nordiska nyttan uppstår när samarbetet sträcker sig längre än det enskilda landets möjligheter att identifiera och hitta lösningar på givna utmaningar.

Därmed mobiliserar man komplementär expertis och komplementära resurser för att hitta lösningar på gemensamma utmaningar. 


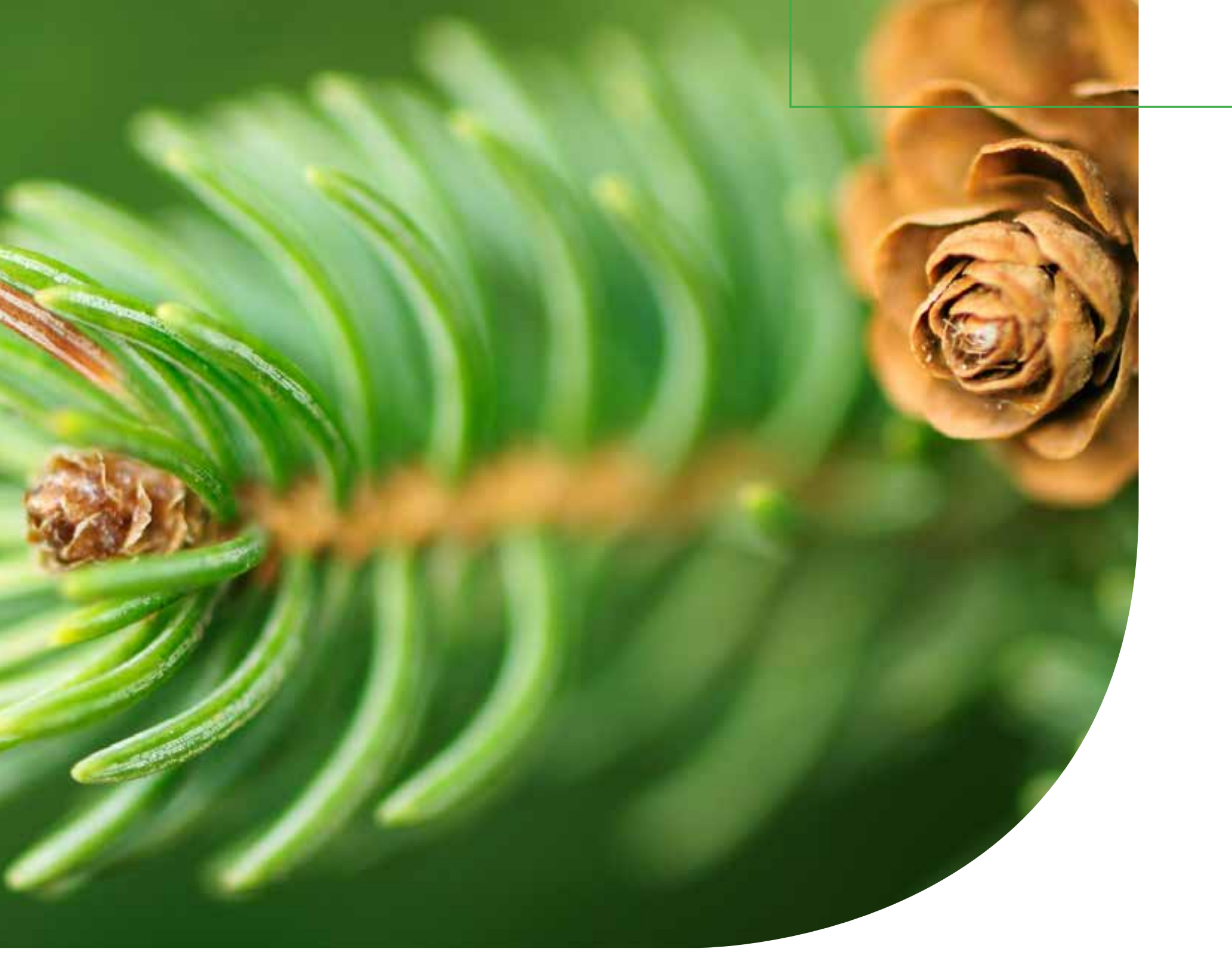




\section{Den nordiska nyttan uppstår när samarbetet}

\section{sträcker sig längre än det enskilda landets}

\section{möjligheter att identifiera och hitta lösningar}

\section{på givna utmaningar.}

Den politiska och samhälleliga utvecklingen under de senaste åren har lett till ett ökat fokus på klimatförändringarna, utmaningar rörande övervikt och den globala livsmedelsförsörjningen, antibiotikaresistens, hållbar utveckling, tankar om grön tillväxt och det biobaserade samhället. Detta är omständigheter som på olika sätt påverkar arbetet inom MR-FJLS. MRFJLS-sektorerna bidrar till att skapa problemen, men de bidrar också till lösningarna, vilka inte kan identifieras och realiseras utan ett aktivt deltagande från MR-FJLS-sektorernas sida FJLS-sektorerna är en del av lösningen.
Samarbetet kommer därför att fokusera på tre övergripande utmaningar, som alla präglas av att de är gränsöverskridande och därför samtidigt är en del av den globala dagordningen som Norden och MR-FJLS-sektorerna står inför:

- Konkurrenskraftig produktion

- Hållbar naturresursförvaltning

- Att upprätthålla och utveckla de nordiska välfärdssamhällena

För de tre utmaningarna gäller att utgångspunkten är hållbar (ekonomisk, miljömässig och social) utveckling. De tre utmaningarna avspeglar att MR- FJLS området har användningen av biologiska naturresurser för mänsklig konsumtion som utgångspunkt. Detta utnyttjande av naturresurserna resulterar i produktion, som vidare innebär ett ansvar för förvaltningen av naturresurserna och som samtidigt ger grundläggande bidrag till att upprätthålla och utveckla de nordiska välfärdssamhällena.
Arbetet i MR-FJLS fäster uppmärksamhet på hur de nordiska länderna kan anpassa sig till de globala utmaningarna samt, där det är relevant, vid hur de nordiska länderna med hjälp av gemensamma bidrag kan påverka de internationella tendenserna i en för Norden positiv riktning.

\section{Konkurrenskraftig produktion}

Utgångspunkten för MR-FJLS-sektorerna är att de genom utnyttjande av biologiska naturresurser producerar varor och tjänster som exempelvis mat, trämaterial, biomassa, energi, friluftsliv och rekreation.

Utmaningarna kopplade till detta är att säkra och upprätthålla en hållbar produktion, som är ekonomiskt lönsam, som värnar om miljön och som bidrar till den sociala sammanhållande kraften över hela Norden.

Att säkerställa och stärka utvecklingen av en konkurrenskraftig och lönsam produktion inom de areella näringarna 


\section{Frågan om knappheten i resurserna och utnyttjan-}

det av dessa pekar också mot nya möjligheter; det som är avfall idag blir värdefulla resurser i morgon.

och livsmedelproduktionen är en stor utmaning. Vad det ger i form av konkurrensfördelar i dag blir standardlösningar i morgon. Man måste därför hela tiden arbeta med konkurrenskraft och lönsamhet genom att ha som utgångspunkt att omvandla politiska prioriteringar till konkurrensfördelar.

Med begreppet grön tillväxt fokuseras på att säkerställa en hållbar utveckling i produktionen, som både ger miljövinster och en stärkt konkurrenskraft. För MR-FJLS är grön tillväxt en viktig punkt på dagordningen, på samma sätt som MR-FJLS-sektorerna är centrala för att realisera grön tillväxt som ett instrument för hållbar utveckling.

MR-FJLS-sektorerna arbetar med produktion med förnybara biologiska naturresurser som bas och har därigenom en central ställning i den samhällsutveckling som nu i vissa sammanhang betecknas som grön tillväxt och i andra sammanhang som det biobaserade samhället. Det är en ständig utmaning att säkerställa en hållbar utveckling i produktionen med tidens aktuella utmaningar.

Utöver välkända problemställningar som globalisering, klimat, livsmedelsförsörjning samt djurhälsa och -välfärd uppstår det hela tiden nya krav, förväntningar och möjligheter för olika typer av produktion, som både kan ge ökade intäktsmöjligheter och samtidigt väcker frågan om vad resurserna kan och bör användas till, exempelvis mat eller energi.

Frågan om knappheten i resurserna och utnyttjandet av dessa pekar också mot nya möjligheter; det som är avfall idag blir värdefulla resurser i morgon.

I en värld med en starkt ökande befolkning finns ett grundläggande behov av att producera mer med mindre resurser. Detta sätter också fokus på resursslöseri i form av outnyttjad biomassa, ett stort matsvinn och bristande utnyttjande av potentialen i de sam- manlagda resurser som blir resultatet av strukturella, tekniska eller andra hinder. Potentialen i det biobaserade samhället ger nya perspektiv och anledning till nordiska reaktioner på hur dessa utvecklingstendenser ska leda till anpassningar i förvaltning och produktion och hur man med utgångspunkt i nordiska styrkepositioner kan påverka den europeiska och globala utvecklingen.

MR-FJLS kommer att bidra till ovanstående genom att vara en leverantör av biobaserade lösningar för företagen och samhället. Efterfrågan på biobaserade lösningar har aldrig varit större än i dag. MR-FJLS kommer under programperioden att bidra till att bemöta de stora utmaningarna.

Ramarna för utvecklingen nationellt skapas av länderna. På det nordiska planet ska samarbetet bidra till att genom dialog och nätverk förbättra de nordiska ländernas förutsättningar för att möta klimatförändringarna och utvecklingen 

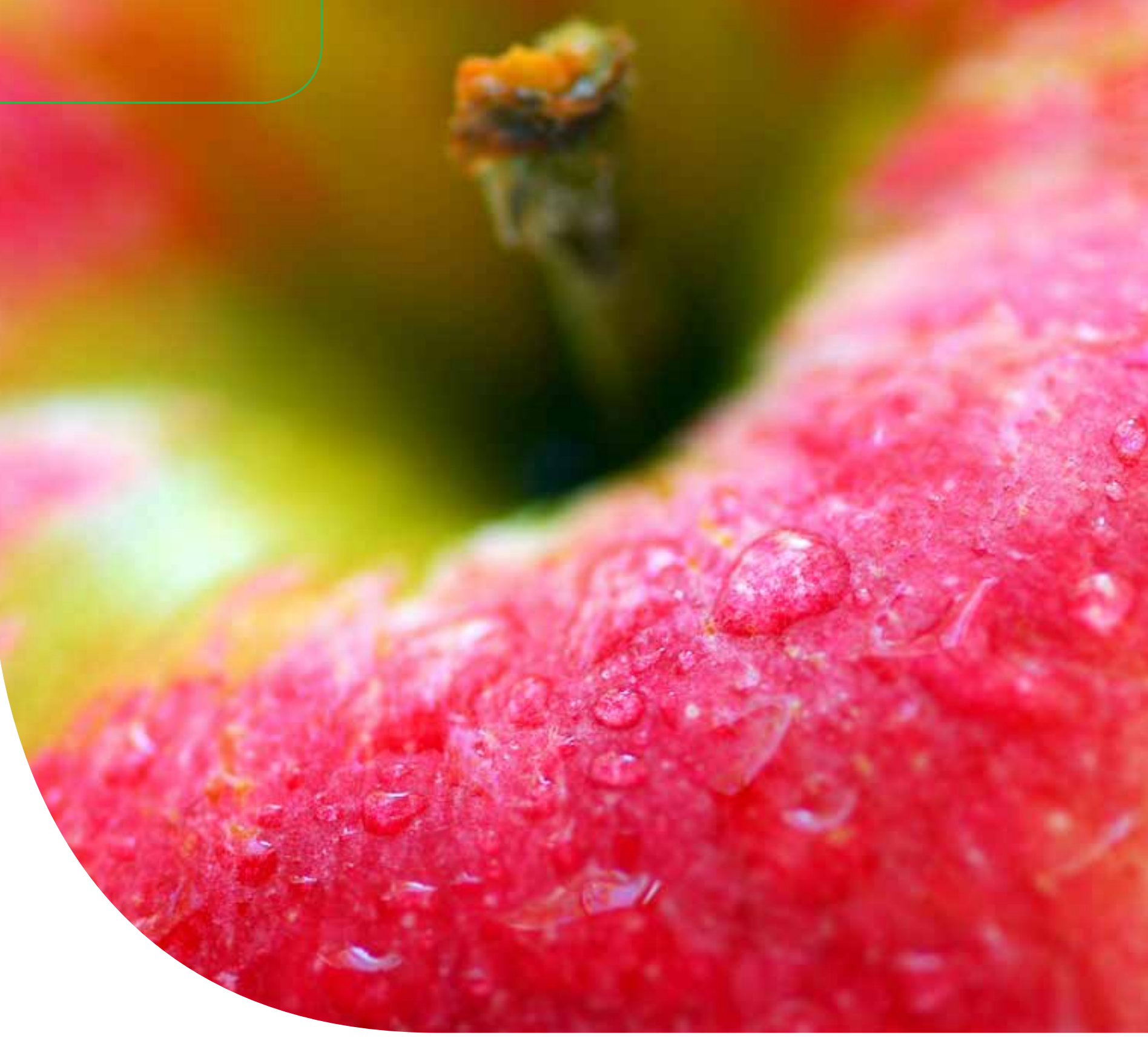


\section{En ansvarsfull förvaltning av marina och färskvat-}

\section{tenresurser har stor betydning för de nordiska}

\section{länderna. För fiskeriförvaltningen är vetenskapliga}

\section{underlag och tillämpningen av försiktighetsansat-}

\section{sen centrala element.}

av det biobaserade samhället samt de utmaningar och möjligheter som är förbundna med dem.

\section{Hållbar naturresursförvaltning}

All samhällsutveckling och produktion bygger på ekosystemens produktion av varor och tiänster och livsuppehållande funktioner. Den gröna sektorn och dess hållbara förvaltning utgör därigenom basen för en hållbar utveckling av ett biobaserat samhälle.

Ekosystemens funktion är grunden för allt mänskligt liv. De bidrar med flera typer av ekosystemtjänster till samhället, som försörjning i form av grödor, djur, trä och fiber, stödjande och reglerande genom klimatreglering och vattenrening och kulturellt genom ökad livskvalitet och hälsa. Forskning och utveckling som utgår från denna bas leder till kunskap som kan omsättas i innovationer och företagande inom de areella näringarna och i övriga samhället. Den gröna sektorn levererar på detta sätt många samhällstjänster.
Produktionen inom MR-FJLS-sektorerna sker med utgångspunkt i användning av biologiska naturresurser. Denna användning måste ske på ett hållbart sätt, och också ta ansvar för förvaltningen av naturresurserna.

Detta är centralt för MR-FJLS. Hållbar betyder ett ansvarigt bruk och produktion av naturresurser som säkrar biologisk mångfald, reproduktion och viktiga ekosystemfunktioner också i framtiden. Förvaltningen av dessa är betydelsefulla utmaninger för näringarnas produktion inom MR-FJLS. Det gäller både det akvatiska och terrestriska ekosystemet.

En ansvarsfull förvaltning av marina och färskvattenresurser har stor betydning för de nordiska länderna. För fiskeriförvaltningen är vetenskapliga underlag och tillämpningen av försiktighetsansatsen centrala element. Genomförandet av hållbara förvaltningsstrategier av de marina och färskvattenresurserna ska basera sig på ett hänsynstagande till hela ekosystemet.

De nordiska länderna är alla underställda internationella krav på bevarande och hållbart utnyttjande av biologisk mångfald och genetiska resurser. Det är ett krav som länderna delvis har valt att lyfta som ett nordiskt samarbete.

De nordiska länderna har under många år varit aktiva bidragsgivare i det internationella samarbetet om genetiska resurser och biologisk mångfald, och det sker inom ramen för bland annat FAO:s Commission on Genetic Resources, Konventionen om biologisk mångfald och de internationella TRIPS-avtalen.

Den ständiga utmaningen för det nordiska samarbetet består i att tillsammans med länderna säkra ett grundläggande bevarandearbete. Det sker genom att utveckla strategier för bevarande av den genetiska 


\section{En av de största utmaningarna på välfärdsområdet \\ är ohälsosamma kostvanor, fysisk inaktivitet och}

övervikt, som utgör ett hot mot en god hälsa i

Norden och stora delar av den övriga världen.

variationen, där den är i naturtillstånd (in-situ-bevarande) och genom strategier för bevarande av den genetiska variationen i till exempel fryst tillstånd (ex-situ-bevarande).

Hållbart nyttjande av genetiska resurser är en utmaning som handlar om att säkerställa att den genetiska variationen tas i användning i produktionen. Det sker bland annat genom växtförädlingsinitiativ, utveckling och förstärkning avhållbar användning av genetiska resurser, vilket kräver fortsatta satsningar inom Nordiska ministerrådet.

MR-FJLS-sektorernas produktion med utgångspunkt $i$ användning av biologiska naturresurser sker i nära samspel med jord och vatten. FJLS-sektorerna använder och påverkar både jord och vatten samtidigt.

Det råder ett samband mellan vattenkvalitet och primär- och livsmedelsproduktionens möjligheter att produ- cera hälsosamma och säkra livsmedel. Och det är inte enbart en utmaning i de nordiska länderna, det är en global utmaning som understryker att vatten vid en svag förvaltning blir en strategisk resurs som långt ifrån alla i tillräcklig grad har tillgång till.

\section{Att upprätthålla och utveckla de nordiska välfärdssamhällena}

Den nordiska välfärdsmodellen genomgår just nu en förändring. Sektorerna inom MR-FJLS skapar grundläggande förutsättningar för upprätthållande och utveckling av de nordiska ländernas välfärdssamhällen, exempelvis livsmedelsförsörjning, livsmedelssäkerhet, och bioenergi samt bidrar på flera viktiga sätt till att säkerställa tillgången till rent dricksvatten. Främjande av en hälsosam kost och en bra livskvalitet bland annat genom tillgång till friluftsliv i en riklig natur och en levande matkultur är också viktiga delar i den nordiska välfärdsmodellen.
En av de största utmaningarna på välfärdsområdet är ohälsosamma kostvanor, fysisk inaktivitet och övervikt, som utgör ett hot mot en god hälsa i Norden och stora delar av den övriga världen. Samarbetet genomförs inom ramen för den nordiska handlingsplanen för bättre hälsa och livskvalitet genom mat och fysisk aktivitet, som ska ge stöd åt de nationella satsningarna. För att stärka fundamentet för bra och enkla kostråd finns samarbetet om de nordiska näringsrekommendationerna och att omsätta dem till direkt konsumentupplysning sker bl.a. genom användning av näringsmärkningen nyckelhålet.

Genom arbetet med Ny nordisk mat fokuserar MR-FJLS på att utveckla en mer mångsidig produktion - både när det gäller produktionsformer och olika storlek på produktionen. Ett resultat av betydelse av det bakomliggande manifestet för ett nytt nordiskt kök är ett ökat fokus på lokal hållbar produktion och inte minst lokalt 


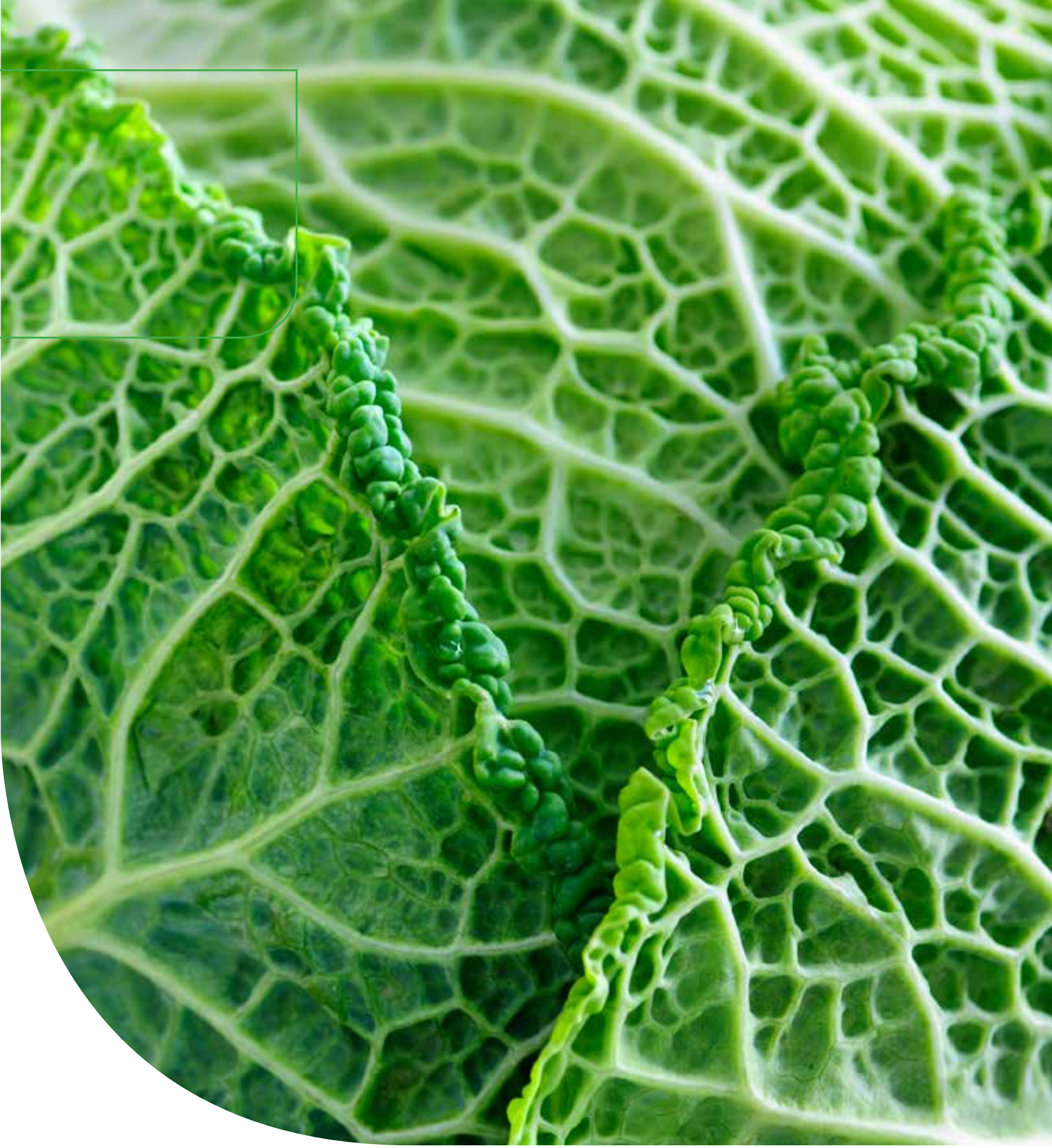




\section{Den ökande handeln i världen ger ett ökat tryck på}

\section{produktionen av livsmedel. Den utmaningen ska}

\section{bemötas genom att stärka de nordiska värderingarna,}

\section{det vill säga fokus på säkra livsmedel och friska \\ djur, som föds upp på ett etiskt försvarbart sätt.}

värdeskapande med potentiellt stora effekter för utvecklingen i kust- och landsbygdsområdena.

Den ökande handeln i världen ger ett ökat tryck på produktionen av livsmedel. Den utmaningen ska bemötas genom att stärka de nordiska värderingarna, det vill säga fokus på säkra livsmedel och friska djur, som föds upp på ett etiskt försvarbart sätt. På de områdena har de nordiska länderna i dag en hög standard. Det är viktigt att upprätthålla denna standard. Norden utvecklar hanteringen av utmaningarna på livsmedelsområdet genom att $\mathrm{i}$ högre grad tillämpa ett helhetsorienterat, riskbaserat synsätt och genom att utnyttja resurserna på bästa möjliga sätt genom exempelvis förebyggande åtgärder.

\section{Den nordiska rösten}

Den nordiska dialogen bidrar till att klarlägga var det råder enighet om givna utmaningar och lösningar och var det råder oenighet. Detta klarläggande ger en bra utgångspunkt för var och när det är möjligt och var och när det är relevant att höja den nordiska rösten.

Samarbetet ska bidra till att främja genomslagskraften hos de gemensamma nordiska positionerna och intressena i internationella processer och forum regionalt och globalt, där det är relevant.

Samarbetet inriktar sig bland annat på att utarbeta bakgrundsmaterial, och när det är ändamålsenligt, att ta initiativ inom ramen för internationella processer som bidrar till att stärka målen i detta ramprogram. Kunskaper om hur de internationella processerna påverkar förvaltningarna i de nordiska länderna utgör också en grund till handling. De nordiska länderna kan lära av varandra och dela erfarenheter även med andra delar av Europa.

\section{Många av utmaningarna för MR-FJLS} är gränsöverskridande och kan bäst lösas genom ett bredare internationellt samarbete i Norden och med grann- regionerna, i Europa eller globalt, där länderna ser det som relevant och där det ger nordisk nytta. Den ökande internationaliseringen med en ökad konkurrens som följd och de nordiska ländernas olika förhållande till EU och andra internationella organisationer utgör både utmaningar och möjligheter i det nordiska samarbetet. De nordiska EU-ländernas åtaganden avseende den gemensamma jordbruks- och fiskeripolitiken ska beaktas och respekteras.

Samarbetet med Nordens närområden, de baltiska länderna, Nordvästra Ryssland och Arktis styrs av särskilda program och riktlinjer, liksom det när det gäller EU:s makroregionala strategi för Östersjöregionen ges möjlighet att göra den nordiska rösten hörd i ett regionalt nordeuropeiskt perspektiv.

Internationella konventioner, avtal och processer påverkar förutsättningarna för förvaltningen och utnyttjandet av naturresurserna från jord och fjord till bord. 


\section{Genomförande}

Utöver ramprogrammet utgör ordförandeskapsprogrammen ett nödvändigt och flexibelt komplement, som årligen kan anpassas enligt förändringar i omvärlden som kräver nya prioriteringar.

Ordförandeskapsprogrammet utformas således så att det uttrycker både ordförandelandets särskilda prioriteringar och övriga samnordiska behov - samt preciserar och kompletterar ramprogrammet. Ordförandeskapet bör samarbeta med det tidigare och det kommande ordförandeskapet för att säkerställa kontinuiteten.

Framgångskriteriet ska mätas i form av samarbetets förmåga att sätta igång och genomföra satsningar och processer som bidrar till att bemöta de tre utmaningarna och uppnå politiska resultat.

Samarbetet inom MR-FJLS bygger på ett omfattande nätverk. Detta nätverk är ett viktigt instrument för genomförandet av ramprogrammet och utgår ifrån det nordiska regeringssamarbetet med ministrar och tjänstemän och vidare till forskare och utövare samt näringslivsorganisationer och -representanter. Målet är att vara det ledande politiska nätverket i Nordeuropa, med relationer till forskning och näringsliv.

Forskning och innovation har stor betydelse för genomförandet av ramprogrammet. Forskningslandskapen på nationell, nordisk och europeisk nivå förändras hela tiden, vilket återspeglas i MR-FJLS genom en allmän utveckling med ökat fokus på forskningspolicy och bemötande av de stora utmaningarna i stället för forskningsfinansiering.

Detta innebär en kontinuerlig utveckling av samarbetet mellan Samnordisk skogsforskning, Nordiska kommittén för livsmedels- och jordbruksforskning, arbetsgruppen Fisk med möjlig inblandning av NordGen och de övriga arbetsgrupperna. Samtidigt är det ett ökat fokus på samarbete mellan MR-FJLS de övriga nordiska aktörerna inom forskning och innovation, som ministerrådet för forskning, ministerrådet för näringsliv, energi och regional utveckling, NordForsk, Nordisk Innovation och Nordisk Energiforskning. Samarbete med andra relevanta aktörerna i det nordeuropeiska forskningssamhället - som samarbete med EFINORD - är viktigt för att skapa kontakter och sprida nätverk i Europa.

Kommunikation är en viktig del av genomförandet och kommer att ske $i$ samarbete med Nordiska ministerrådets kommunikationsavdelning samt relevanta nationella kommunikationsaktörer. Kommunikation och dialog är viktiga instrument för samarbetet och bidrar till att sprida kunskaper och idéer om hur det nordiska samarbetet kan skapa lösningar för de nordiska länderna. Lösningar som leder till bra och acceptabla anpassningar till internationella strömningar eller som ger möjligheter att med hjälp av samarbetets och ländernas egna bidrag påverka den internationella utvecklingen samt strömningar och utvecklingen i en riktning som är positiv för Norden.

En utvärdering av handlingsprogrammet genomförs i slutet av programperioden. 

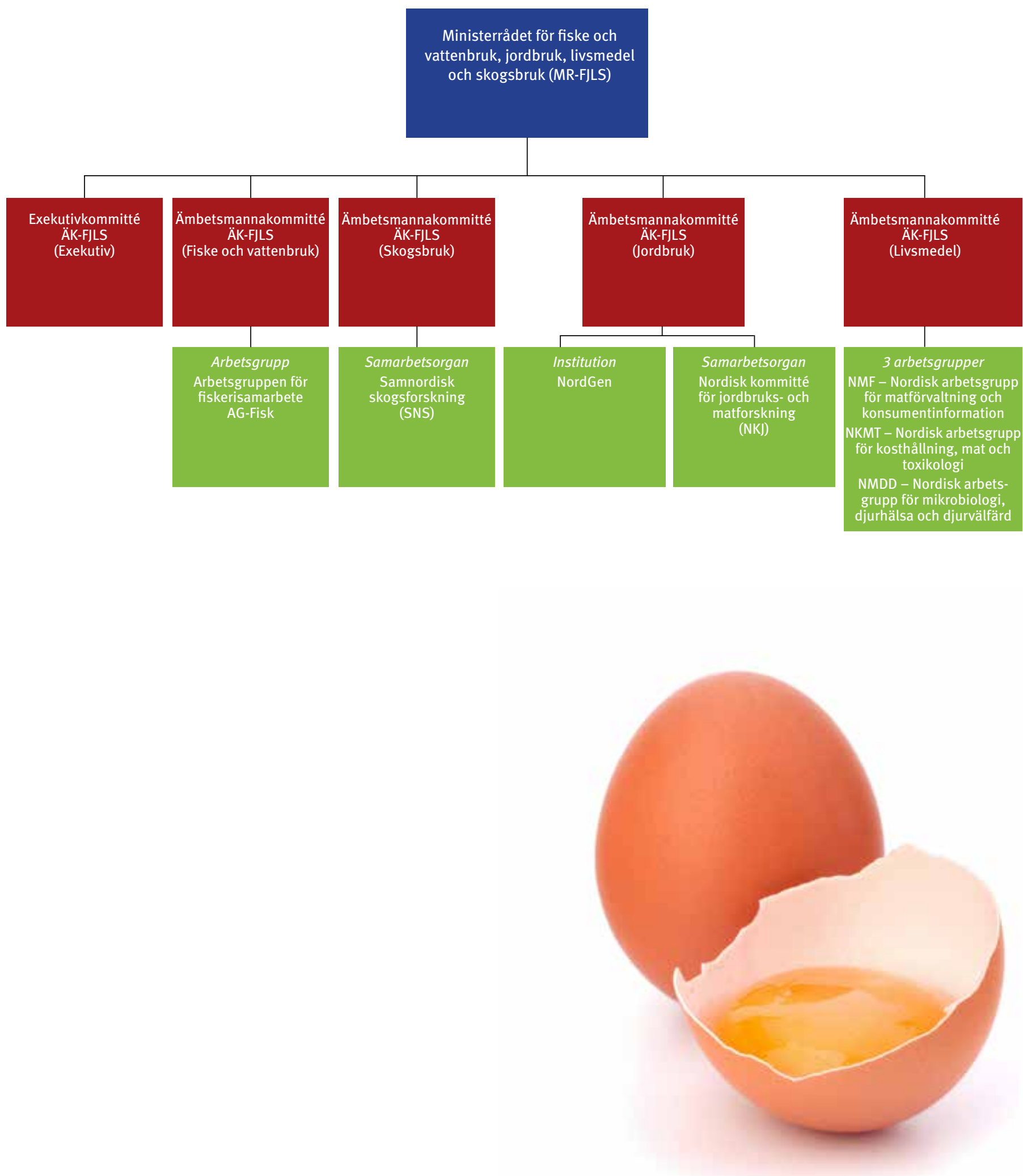


\section{norden}

Nordiska ministerrådet

Ved Stranden 18

DK-1061 København

www.norden.org

Ramprogram för det nordiska samarbetet inom fiskeri och vattenbruk, jordbruk, livsmedel och skogsbruk 2013-2016

Ramprogrammet anger inriktningen för det nordiska politiska samarbetet inom fiskeri och vattenbruk, jordbruk, livsmedel och skogsbruk under perioden 2013-2016 inom Nordiska ministerrådet. Ramprogrammet ger möjligheter och beskriver de centrala utmaningarna på området.

Ordförandeprogrammet för de enskilda åren preciserar och kompletterar ramprogrammet. Dessa utgör tillsammans handlingsprogrammet för samarbetet.

Utöver detta har i ramprogrammet beaktats de prioriteringar och strategier inom Nordiska ministerrådet som sätts upp av statsministrarna, samarbetsministrarna och övriga ministerråd när man arbetar med teman och problemställningar inom vilka MR-FJLS kan bidra. 